This item was submitted to Loughborough's Research Repository by the author.

Items in Figshare are protected by copyright, with all rights reserved, unless otherwise indicated.

\title{
How dirty is Jayne Anne Phillips?
}

PLEASE CITE THE PUBLISHED VERSION

PUBLISHER

(c) MHA

LICENCE

CC BY-NC-ND 4.0

REPOSITORY RECORD

Jarvis, Brian. 2019. "How Dirty Is Jayne Anne Phillips?”. figshare. https://hdl.handle.net/2134/339. 
This item was submitted to Loughborough's Institutional Repository by the author and is made available under the following Creative Commons Licence conditions.

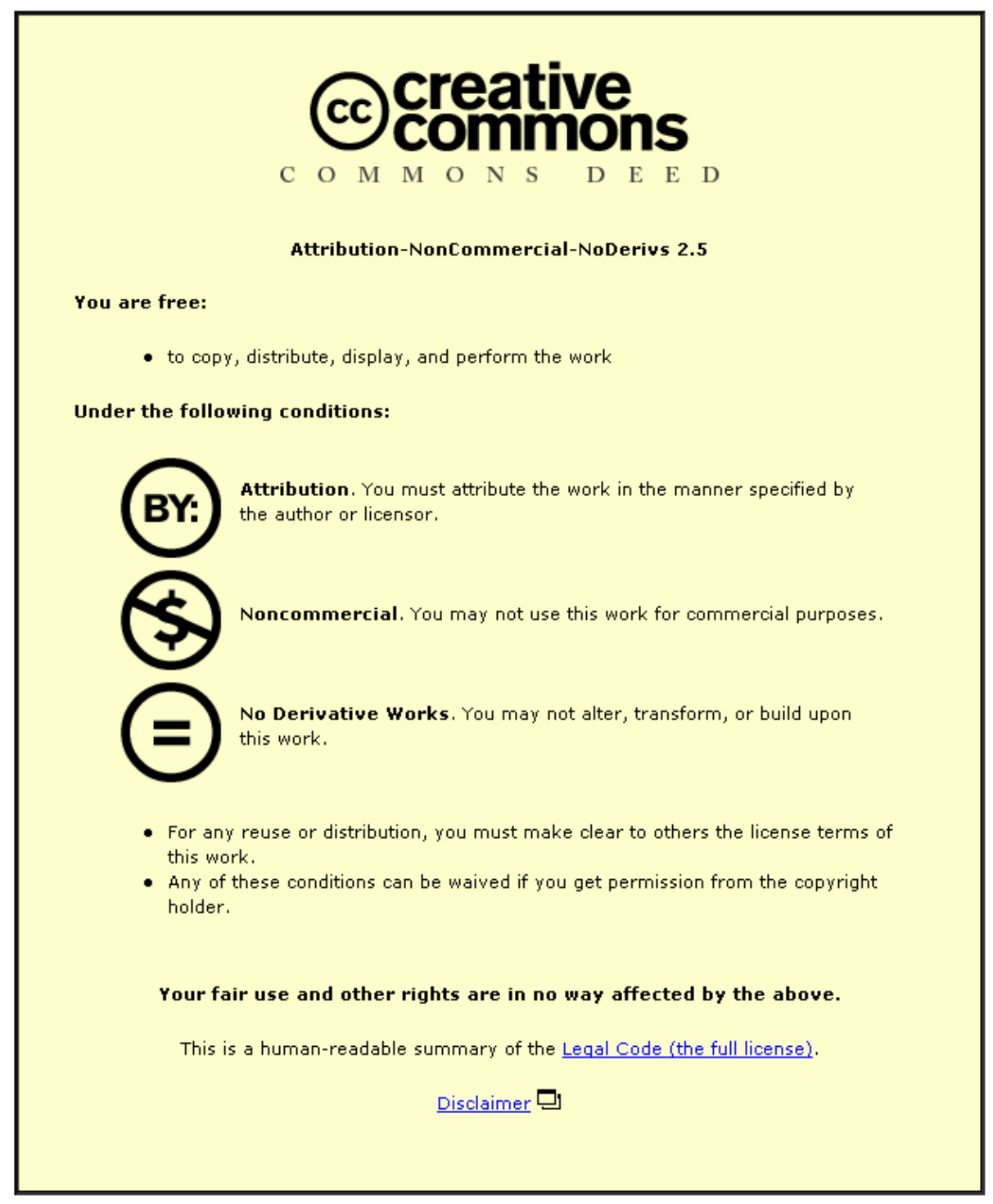

For the full text of this licence, please go to: http://creativecommons.org/licenses/by-nc-nd/2.5/ 


\section{Loughborough $\checkmark$ University}

This article has been submitted to Loughborough University's Institutional Repository by the author.

\section{How dirty is Jayne Anne Phillips?}

\section{Brian Jarvis}

There seems to be a consensus amongst critics of American short fiction that something happened in the late 1970s, a new school emerged with a distinctive style and set of preoccupations. This school, with Raymond Carver as head teacher, included amongst others, Bobbie Ann Mason, Richard Ford, Tobias Wolff and Jayne Anne Phillips. Both individually and collectively these writers have been tagged with a variety of labels: 'dirty realism', the most conspicuous term, has been supplemented by 'new minimalist fiction', 'new realism', 'K-Mart realism' and 'dirty surrealism.' The number of labels here suggests that whilst there is agreement on the fact that something happened to the American short story at this time, there is less unanimity on the precise nature of this happening.

There have been at least five distinctive, though not necessarily exclusive, definitions associated with these labels. Firstly, some critics have focused upon the class dimension to this fiction, its fascination for blue-collar lives. Secondly, there has been significant critical attention to the formal aspects of this fiction, especially its minimalist economy of expression. Thirdly, some critics, preferring the terms 'new realism' or 'K-Mart realism', have focused upon the relationship between this fiction and contemporary socioeconomic developments, in particular, developments in consumerism and postmodern culture. Fourthly, certain members of this school have been singled out for the alternative label of 'dirty surrealist', because of the psychoanalytical self-consciousness displayed in their work. Finally some critics, focusing on sociopolitical history, have interpreted this fiction in relation to the rise of the New Right, reading it as a critique of the dominant discourses of Reagan's America, especially in relation to hegemonic definitions of gender and family.

It is probably worth mentioning that, in some quarters, there have been vigorous challenges to the very concept of a dirty realist school. 'Dirty realism' has been dismissed as a marketing ploy by publishers to stimulate dwindling sales, 
especially in the U.K, in contemporary American fiction. In this vein, Nick Hornby has described 'dirty realism' as an 'inadequate categorisation' that 'doesn't mean very much at all.' ${ }^{2}$ In this paper I aim to explore some of the definitions paraphrased above and offer some of my own in relation to the work of Jayne Anne Phillips. In particular I want to examine various meanings of the 'dirt' in 'dirty realist' and whether it 'means very much at all' in relation to Phillips' two short story collections, Black Tickets (1979) and Fast Lanes (1987). ${ }^{3}$

I live in the gutters of dog manure, wine and urine; in the sewers which eat these melodies delivered by the sprays of sweeper trucks ('Gemcrack', Black Tickets, p.255).

So, how dirty is Jayne Anne Phillips ? In a literal sense much of her short fiction is positively filthy: toilets seem to be a favourite location, with 'urinals ruststained and scenting out a poison sweet of piss ... reminding you of all your sick vomits' ('Black Tickets', Black Tickets, p.54, p.56). Leaving the lavatory the Phillips' reader often finds themselves in dilapidated motels, strip joints and porn shops, rat-infested cinemas, dirt farms and dusty border towns. Dirty locations are mirrored in dirty bodies. The narrator in 'Gemcrack', for example, has a dual obsession with the filth of the city and his own body: 'I want to peel back the skin layer by layer, find the smell and wash it. I smell of something cut up, limp curls on boards, limp curled skins of onions ... The Bronx smelled of garbage left in a heat, smelled of a whole city wasting' ('Gemcrack', Black Tickets, p.258, p.262). In 'Under the Boardwalk', a poor white high school girl performs an abortion on herself in a field, but the family dog brings the aborted foetus back to the house. This 'bringing it back home', returning the reader to the unruly materialism and messiness of the body, is often at the heart of Phillips' short fiction.

To use the critical terminology initially developed by Julia Kristeva, Phillips' fiction expresses a fascination with the abject. In Powers of Horror: An Essay on Abjection, Kristeva examines the opposition between the clean and the dirty: a clean, stable subject is located in the symbolic order through the disavowal of the dirty, the corporeal filth typically associated with the maternal Other in a patriarchal order. Kristeva suggests that the abject is disgusting and fearful because it ties the subject to the impure, to animality, to disease, waste and ultimately to death. Abjection involves objects and experiences which disrupt the stability of the symbolic, which 'disturb identity, system, order.' ${ }^{4}$ Similarly, in Phillips' writing, the fascination with dirt and waste, both geographical and corporeal, represents a recognition of drives that constantly threaten to disturb identity, system and order. The failure of abjection 
generates crises in subjectivity and signification and these crises are where Phillips locates her work. If the symbolic is defined as that space in which the subject can enunciate and experience the body as its own, Phillips' dirtiness returns a sense of the body's otherness, as object, not subject.

Phillips' fascination with the abject and bodily otherness also manifests itself in a preoccupation with illness and forms of disability. Around half of the stories in Black Tickets and Fast Lanes are preoccupied with or feature ill health: cancer and $\mathrm{TB}$, ulcers and tumours, poisoning and accidental injury, problems associated with periods, pregnancy and menopause, 'hysterical' blindness, 'mystery' illnesses, a range of deformities. This preoccupation with what we might call the non-hegemonic body needs to be historicised. Phillips' short fiction was published during a period in American history, the late 70s through to the mid-80s, which saw the consolidation of a body culture and its antithesis in AIDS. On one side we see a dramatic upsurge in obsessions with health, fitness and image, fantasies of total control over the body through diet, exercise, surgery, cosmetics and clothing. On the other side we see the carefully manufactured hysteria and demonology surrounding HIV. Against this backdrop Phillips' fiction focuses on what is repressed by body fascism: fears about the body breaking down, loss of control and ultimately a neurotic denial of death. One of the main elements in this fictional treatment of illness is that, like Susan Sontag, Phillips seeks to purify illness of 'metaphoric thinking.' ${ }^{5}$ At a time when such thinking was enjoying a renaissance, illness is sensitively represented in her work not as a sign of something else, a punishment or a moral flaw for example. Illness signifies itself and is thus portrayed without the sorts of stigma which were alluded to by a characteristic Reagan denial, made during a television interview, after he had an operation to remove a tumour. 'I didn't have cancer. I had something inside of me that had cancer and it was removed.' ${ }^{6}$

Abjection does not operate only on an individual level, its mechanisms can also be detected in social relations. The working class, the underclass and various racial and ethnic groups constituted what could be termed a socioeconomic abject in Reagan's America. Large numbers of undesirables were symbolically expelled from the national corpus, disavowed to ensure the health of the collective body. Phillips is typically drawn to the those defined in social terms by the dominant culture as 'dirty' or 'trash', to the lives of the rural and urban poor, hookers and drunks, poor whites and mine workers living in 'perpetual thirties'” towns ('Country', Black Tickets, p.233). In 'Black Tickets', 'El Paso', 'Mamasita' and 'Country', she also surveys racial myths about the 'otherness' of black and Hispanic Americans. These and other stories often dramatise collisions between races and classes and whilst generally managing to 
resist a casual romanticisation, they often associate the socioeconomic abject with a vitality, an energising difference that appears to be missing from Phillips' white middle class homes. The narrators in 'How Mickey Made It' and 'Blue Moon', for example, each experience a productive disembourgeoisement and dynamic class collisions feature significantly in 'The Patron' and 'Bluegill.' One of Phillips most compelling explorations of racial contiguity is the title piece of her first collection.

'Black Tickets' is narrated by a white drug dealer who grew up in a 'suburban clap-trap house' complete with 'fake-maple dinette’ ('Black Tickets', p.55). It hinges on his relationship with a West Indian immigrant known as 'Jamaica Delilah'. Formally in 'Black Tickets' one can detect a Beat homage, especially to Burroughs, but this is not the dominant generic code because Phillips chooses to investigate race through the dark glass of the noir tradition. In classical noir mode 'Black Tickets' has a shadowy, nocturnal urban setting and it slides insouciantly between sex, violence, crime and moral degeneracy. Appropriately enough, most of the narrative is set in and around a dilapidated cinema, the 'Obelisk', used mainly by prostitutes and drug dealers. Jamaica Delilah, like her biblical namesake, turns out to be a betrayer, a black femme fatale and her victim, the narrator, tells his story retrospectively from prison.

'Black Tickets' is thus a noir narrative about race, a tale doubly concerned with blackness, but it is important to emphasise that Phillips does not deal with blackness per se, so much as white sexual fantasies about black. ${ }^{7}$ Delilah becomes the narrator's ticket to a world beyond anything he has known during his upbringing in a sanitised white suburbs: 'No one else could take me; pay my way with what your skin knows' (p.59). Much of the story is devoted to the narrator's desire to shape blackness into signs, to signify the Other and thus solidify his sense of self:

\begin{abstract}
And I could wonder about shaking you until the ice cracked and all the deep black poured out, textures of blacks: black of thick tar, black of satin, corduroy black, waxen and petaled black of death masks, orchid black, black of cashmere beds and the moonless impetigo night, cancer black and black of inheritor insects, black of wet rope and burns and black and black and black I saw in your icy throat. I pulled you up and shook you limp; Jamaica, you black doll, wobbling like a dead girl sewn of old socks (p.58). ${ }^{8}$
\end{abstract}

Dirty and diseased, dangerous and desirable, Delilah becomes the narrator's archetypal noir goddess. However, just as she eludes him physically in the tale (by running off and leaving him in jail), she also eludes him semantically, leaving him imprisoned by racist cliché. The more he tries to articulate the Other the further she moves away:

I might have finished with my hands at your throat. Where would we all be if I had; Obelisk 
still a destitute fortress and Neinmann holding court a few thousand richer, rejoicing like a fascist Munchkin in his broken-down Aryan heart: witch, witch, the mean old witch, the wicked witch is dead. And Raymond, where would he take his services; where would he find a seer, a Mafioso Beatrice like yourself, a movie house scam the length and breadth of $\mathrm{C}$ Street ? He watched me but you watched him. Watched him and touched him, kept him in your apartment like an accomplice court jester. And me Jamaica, I'd be in one of several Bolivias mourning your loss, bleeding my own menses of regret at blowing the tracks of the only train that could push me past a raunchy perfection; a save-my-soul rattle only the devil searches out. I love you the way I love nightmare, secrets coming up like smoke through a grid; the way I love mirrors shattered but still whole, reflecting the foolish image in a hundred lit-up fragments. No one else could take me; pay my way with what your skin knows (p.59).

Tracking through this labyrinth of intertextual echoes - from medieval myth to beat slang, from Dante to The Wizard of $\mathrm{Oz}$ - the reader ends up back in the noir city: smoke swirling up through grates on the mean streets and the hall of mirrors shattered in a shoot-out. The important thing to note about these figurative clues, however, is that they fail to mesh as a net capable of snaring the femme fatale, instead the narrator's projections simply reflect on his white college education and knowledge of popular culture.

The mirror, 'shattered but still whole' is perhaps suggestive of a transitional phase, a moment between the semiotic and the symbolic. This is why the narrator's attraction to the Other cannot be fully articulated, it is largely pre-lingual. He tries to interpellate his relationship in the symbolic, but his desire (the fusion of love and hate, the absolute dependency on a powerful, nurturing but threatening Other) seems to belong to the semiotic. The elision taking place here between racial Other and preoedipal Mother is most striking at the end of the story, in the moment when the narrator falls asleep in a bath whilst lying between Delilah's legs (drifting back to the blackness of the womb). Later, when he awakes, she has gone and he finds himself covered in her freshly cut hair. This denouement clearly invokes biblical legend, associating Delilah, hair and betrayal, but it is important to note that it also contains carefully overdetermined psychoanalytic possibilities (especially in relation to anxieties associated with maternal abandonment, castration and birth).

\section{2.}

... every Daddy wants his daughter ('Stripper', Black Tickets, p.73).

Returning to the opening definitions that were offered of dirty realist writing, Phillips certainly confirms the notion that this fiction focuses on society's dirty underbelly. 'Black Tickets' exemplifies this concern with the socioeconomic abject 
but, simultaneously, it also confirms the definition of dirty (sur)realism that concentrates on psychoanalytical self-consciousness. In a colloquial sense Phillips' fiction is dirty because it is preoccupied with sex - S\&M, homosexuality, incest, paedophilia, voyeurism, numerous fetishes - which is typically laden with oedipal baggage. Psychoanalytical self-consciousness manifests itself in repeated forays into the family romance, psychosis and a general fascination with the uncanny, desire, sexual development and the maternal body. At the same time, especially in Black Tickets, the persistent association of desire with various neuroses, family conflicts and violence, against others and the self, sometimes threatens to suggest a barely muted Puritanism.

Dreams also play a large part in Phillips' work. This occurs both at a formal level, where desire is often articulated through phantastic, surreal and synaesthetic tropes and also in terms of narrative content. The centrepiece of many of her stories, such as 'Lechery', 'Bess', 'Bluegill' and 'El Paso', are puzzling dream sequences in which she collapses conventional epistemological hierarchies - this realm is not more or less real, it simply is. She seems to share a Freudian faith in the significance of the 'royal road', but she rarely displays a Freudian faith in the legibility of the signs encountered en route. Typically the Phillips' dream sequence is opaque, resistant to interpretation rather than a key to meaning. Dreams, however, are not the only space in which this opacity is apparent.

Psychology in general terms in Phillips' work is often cloudy with a distinct emphasis upon the primacy of the unconscious and the unknowable. Her characters rarely grasp their motivation or fully comprehend their behaviour, instead they are permitted minor and often obscure developments in consciousness, almost Jamesian in their subtlety. Sometimes the primacy of the unconscious erupts into madness, as in '1934', 'Rayme' and 'Gemcrack'. '1934' offers a reworking of an established tradition in literary representations of madness, featuring a madman in an attic (as opposed to the familiar madwoman) and a young girl caught on the cusp between the vigours of a child's fantasy life and adult definitions of insanity; 'Rayme' is an extended treatment of the borderlines between the eccentric and the dangerously unstable; and in 'Gemcrack', a serial killer with an obsessional foot fetish follows orders from a dead uncle to kill women, thus sending them 'home.'

Despite being something of a generic departure for Phillips (into the realms of Criminal Gothic), 'Gemcrack' is in one respect representative of the mainstay in her work. Black Tickets and Fast Lanes persistently interrogate meanings of home and 
the American Family. 'Family' and 'Home' have of course always been privileged signs for patriarchy, but it is important to note that there was a dramatic resurgence in traditional conservative definitions of these terms during the period that Phillips' short fiction was produced. Throughout political discourse at this time, in church rhetoric during a fundamentalist revival, across advertising and popular culture, a saccharine paradigm of the Great American Family was consolidated. Dirty realism offered, amongst other things, a dissenting intervention in hegemonic discourses surrounding this paradigm. The legibility of the dominant culture's privileged signs like 'Family' and 'Home' - is often taken for granted. In dirty realist writing these shibboleths become polysemic and far less stable.

The opening story in Black Tickets focuses on an unnamed narrator poring over family snapshots. 'Wedding Picture', Phillips' inaugural family narrative, sets the tone for subsequent framings. 'Family', the ideological touchstone of the New Right, becomes quite cryptic in this lyrical short short, compiled from evocative clues, ambiguous gestures, voluminous silences. Phillips consistently eschews a grand narrative of the American Family and even when her figurations appear to converge with dominant definitions they tend to work towards the deconstruction of patriarchal chimera. At the end of 'The Heavenly Animal, the narrator, Jancy, recalls a Xmas day in her childhood when everything appeared to be in its place: the family were together in the car, Dad was at the wheel and a deer flashed by to complete the Yuletide sketch. But this recollection is laced with ill omens: her brothers are playing with toy guns, her mother's earrings are like 'wreathes', the road they are driving on is swallowed up by trees. Jancy's Xmas card image of family life cannot even be sustained in nostalgic memory and is revealed to be a weak defensive gesture reverted to at a moment of crisis (having just run over a deer).

Black Tickets and Fast Lanes converge on the 'dirty secrets' hushed up by patriarchal ideology, the problems of separation, divorce, violence, incest, breakdowns in communication and varieties of abuse. Whilst hinting at the impact of changing class positions, generational tensions and sexual history, the Phillips' short story rarely ascribes singular determinate causes to the problems of family life, so that, on occasion, it begins to feel as though she views the term 'dysfunctional family' as tautological. This is not to say, however, that her treatment of various family members is uniform or entirely despondent. Fathers, mothers and children are interestingly differentiated throughout her work and there are instances of contact, care and communication, especially between mothers and daughters, brothers and sisters, who often lose themselves in each other and seem to enjoy pre-lingual bonds. 
In almost all of her writing on the family (and almost all of her writing is on the family) Phillips tends to maintain a decorous distance from the Father, relative to the immediacy of her engagement with mothers and children. Fathers never partake of the familiar symbiosis that she traces between other family members. The Phillips' Father remains distant, imposing, and never fully present. Once again this needs to be related to sociohistorical context, because the 80s saw something of a renaissance for the figure of the Patriarch. Contrary to this in much of Phillips' work the family is characterised by either a marginalised or absent father figure. She depicts a relative decline in paternal authority within the home, often relating this to the increased economic independence achieved by working women. This is not depicted as a fullscale de-oedipalisation of the American family, however, more as a withering of gender polarities.

This withering of gender polarities is also apparent in relation to the maternal. 'Mother' functions primarily as a verb in Phillips' writing: daughters regularly mother their mothers, as for example in 'Home' and 'Souvenir', whilst lovers mother each other. Phillips is clearly fascinated by the reproduction of the maternal role, its limits and its protean possibilities. In 'Fast Lanes' the thrust of the conventional road narrative is reversed: a woman is depicted as the self-destructive rebel who doesn't want to be tied down and her male partner assumes a traditional maternal aspect. He holds her in the water at one stage, making 'low disconnected words, mother sounds and lullabies' ('Fast Lanes', Fast Lanes, p.39). When he picks her up in his arms it becomes less the gesture of a romantic hero and more motherly, making her feel like ‘a baby, a frozen six-year old baby’ (p.64). This sort of inversion is not untypical in Phillips' writing and confirms Kristeva's comment in 'Stabat Mater', that 'the territory of the maternal is not a space confined to biological characteristics; it is the position a subject, any subject, can assume towards the symbolic order.' ${ }^{9}$

The bond between Mother and Daughter is of central significance in Phillips' work and tends to fall into two broad categories. Some seem to enjoy almost mystical synchronicity, even down to menstrual cycles and for these most of the important communication is non-lingual, a matter of looks, gestures, touch, not outside the symbolic, but certainly closer to the semiotic. However, on other occasions, Phillips' daughters suffer from matrophobia, as defined by Adrienne Rich: not fear of one's mother so much as fear of becoming one's mother. Throughout the stories in Black Tickets Phillips explores the relationship between mother and child exclusively from the latter's perspective. She departs from this in some of the stories in Fast Lanes 
(published after the birth of her own children) and 'Bluegill' stands out prominently in this respect as her most extensive exploration of maternal subjectivity.

'Bluegill' takes the form of an extended lyrical address by a mother to her unborn child. Dispensing with conventional Victorian iconography, the imagery in the opening descriptions captures a complex of emotions, in which the foetus appears anything but human: it is called 'fish', 'shark-face', 'predator', 'fanged one', 'sucker' ('Bluegill', Fast Lanes, p.69). It has become a commonplace in readings of the vampire to suggest an analogy between the relationship of vampire-to-victim and mother-to-child: a powerful presence enters and leaves our room at night, after an exhilarating exchange of fluids. Phillips inverts this commonplace and extrapolates it back into the womb by using vampiric tropes to describe the foetus. But vampire imagery is only one of the frames of reference invoked in 'Bluegill'. To describe the life inside her the narrator sifts through the discourses of romance (Lover), marriage (Spouse), economics (Employer), horror (Ghost), mythology (Hermaphrodites, Percheron) and fairy tale (the Pied Piper). Motherhood becomes a densely inscribed textual space: 'I am only witness to a language.' ('Bluegill', Fast Lanes, p.77). The struggle for names that takes place here is comparable to the struggle described earlier in 'Black Tickets'. In both narratives a crisis in interpellation, specifically in trying to name the Other, results in a crisis in subjectivity. In 'Bluegill' the impossibilities that the mother meets in trying to name, to call into being her unborn child, suggests that her maternal subjectivity is itself gestating.

As previously mentioned, most of Phillips' writing on the family adopts the perspective of the child or adolescent. From this vantagepoint she often crafts bildungsromans which eschew clumsy polemics, where the lessons are not always clear. Her fascination with youth can in part be connected to her interest in gender identity, with subjects before a narrow gender role has been irrevocably fixed. Much of her understanding of gender foregrounds fluidity, a fluidity that challenges the fixity being rigorously enforced by a resurgent patriarchy in Reagan's America. Continuing the parallels that have been offered with Kristeva's work, one could mention here her essay on narrative representations of adolescence. In 'The Adolescent Novel' Kristeva talks about this figure as the 'innocent and justified pervert.' 10 This captures exactly the nature of Phillips' children and adolescents. In 'Lechery', 'Blue Moon', 'Bess', 'Country' and 'How Mickey Made It', the protagonists are naïve but hungry for sexual knowledge and embark eagerly on the passage from not-so-innocent to initiated. For Kristeva adolescence in particular is a time in which the boundaries of sexual difference and identity elide: 
The frontiers between differences of sex or identity, reality and fantasy, act and discourse, etc., are easily traversed without one being able to speak of perversion or borderline - and perhaps this would only be because these 'open structures' [adolescents] find themselves echoing the fluidity, i.e., the inconsistency of a mass media society. ${ }^{11}$

Such crossings preoccupy the innocent and justified perverts in Phillips' work and her muted bildungsromans are a crucial strand in a critical rewriting of hegemonic discourses surrounding the American Family.

3.

'Each music lasts, forgetful, surfacing in the aisles of anonymous shops.'

('Bluegill', Fast Lanes, p.75)

The final major definition of dirty realism that I would like to explore in relation to Phillips' work follows on from Kristeva's reference above to the media society. Pursuing the question of Phillips' postmodernity, Joanna Price has argued that an interest in mass media is a defining feature of Phillips' work. Price compares Phillips' debut novel, Machine Dreams, to Bobbie Ann Mason's In Country as novels about the lives of people living 'at the intersection of global postmodern and smalltown American cultures.' ${ }^{12}$ Price scrubs off the dirty label and brands Phillips a 'new realist.' New realism 'makes constant references to brand names, television programmes and mass media personalities.' ${ }^{13}$ These are lumped together as 'common ephemera' which new realist writers approach with an 'ironic reflexivity'. ${ }^{14}$ Price continues:

The reality evoked by these writers is a theatre of shadows, cast by the images and objects of consumer culture over a web of lacks and losses ... an image without a body, a network of desires which can find no material resting place. Consumer culture must create in its subjects a perpetual sense of loss, of desire for the restitution of an impossible, lost object, a desire which can only be temporarily assuaged by the ineluctable metonymy of objects and images which confines the individual in the detail and the image. ${ }^{15}$

There is a persuasive critique of consumer culture here, but its relevance to Phillips' work is less convincing. The issue of agency is critical, since Black Tickets and Fast Lanes (not to mention Machine Dreams) seem more concerned with new subject positions, alternative centres, than in a passive decimation of subjectivity and corporeality by consumer culture. Contrary to the suggestion that new realist writing surveys 'an image without a body', as I have argued, Phillips repeatedly foregrounds the abject, the visceral, the ineluctable physicality of the body. 
Bobbie Ann Mason has responded well to the claim that the references to popular culture in her work are 'ironic', designed to show how trashy and transient the postmodern world is:

I think I use the references more organically, to say, this is the world of the characters and this is what they like. The fact that the culture may be shallow doesn't mean that the characters are shallow, or that they are stupid for enjoying it. ${ }^{16}$

Much the same can be said of Phillips. She is equally interested in what people do with consumer culture as with what it does to them: the way in which people construct creative possibilities within it, are critical of it, fight, fuck and fall in love to its soundtracks. The argument that suggests this fiction revolves around the fragmentation of subjectivity by decentred signs from popular culture may reveal less about Phillips’ work than the critic’s own prejudices.

Phillips' short fiction is packed with illustrations of a critical engagement with popular culture. In 'Home' the narrator complains about the television her mother watches incessantly: 'The shows are all alike. Their laugh tracks are conspicuously similar' ('Home', Black Tickets, p.8). Similarly, in 'How Mickey Made It', the eponymous narrator comments on how his sister 'sits in the easy chair and watches TV like a TV machine ... it's plain you hate yourself' ('How Mickey Made It', Fast Lanes, p.7). Alternately, Mickey constructs his identity through rock music. He imagines himself, the way he performs in public and for his lovers, like a character from a rock music documentary. In the process he rarely transcends pop culture banalities, but still the focus is on his energy, humour and creativity. In 'Home' the narrator rewrites romantic fantasies found in Reader's Digest, transforming them into folkloric fables before significantly turning old copies into wastepaper baskets. In 'Blind Girls' Jesse similarly offers a creative reworking of horror B-movie scenarios and in 'Bluegill', even that most archetypically banal emblem of commodity culture, supermarket muzak, is shown to possess a potential, a continuity with myth and legend, inconsistent with the notion of 'ironic reflexivity': 'Each music lasts, forgetful, surfacing in the aisles of anonymous shops' ('Bluegill', Fast Lanes, p. 75).

Occasionally Phillips does deploy ironic disjunctions in her references to pop culture. In 'Cheers' the sewing women live in 'skinny houses on a mud alley' whilst keeping themselves going with T.V programmes like 'Queen for a Day' and postcards of Florida ('Cheers', Black Tickets, p.203). In 'Under the Boardwalk' there is an even more powerful discontinuity, between the romantic promise of the rock 
ballads a young girl hears on the radio and the grisly realities of having to perform an abortion on herself: lying by a creek on a horse blanket, screaming in pain, is juxtaposed with the 'easy moaning' of the Drifters, 'on a blanket with my baby, that's where I'll be' ('Under the Boardwalk', Black Tickets, p.100). Phillips recognises the distance between sanitised media fantasy and a dirty reality, but this is not done with an assured 'modernist' irony. Whilst the fantasies may be ephemeral the desires that fuel them have substance and thus individuals are not entirely confined 'in detail and image.' Characters in Phillips' short fiction often understand themselves in relation to details and images from popular culture - from rock'n'roll songs, road movies, westerns and romances - but rather than an elitist dismissal of this 'common ephemera', the author focuses on how the signs of consumer culture can acquire meaning and value through peoples' experiences.

Price's critique may be locked in a strictly Lyotardian definition of postmodernism that fails to recognise that beyond the collapse of grand narratives, there can be a valorisation of micro-narratives, a celebration of small scale stories, even those from popular culture. She concludes her essay with a definition of new realist writing that repeats this omission: 'It is conflict between a homogenising postmodern culture and forms of diversity, whether they be sexual, racial, or those of class, which is explored throughout new realist writing.' ${ }^{17}$ This ignores the possibility that Phillips is interested in the articulation of diversity within postmodern culture as well as against it. The binary opposition that Price offers is too straightforward because Phillips shows how forms of diversity do not exist outside of postmodern culture, they are inevitably constructed within it. ${ }^{18}$

Returning briefly to the subject with which I began: labeling. One must inevitably have reservations about the efficacy of labels in relation to a writer with the range of Jayne Anne Phillips. Both within and between her two short story collections to date there are major significant variations in form and subject. Geographically, in terms of setting and against the notion of an archetypal dirty realist location, she ranges from country to city, from the suburbs to the small town, from Deep South to West Coast. Historically, Black Tickets and Fast Lanes move from the fin-de-siecle to the 1980s. Stylistically, Phillips ranges from the colloquial ('How Mickey Made It') to the densely figurative ('Gemcrack'), from fairy tale and myth ('Bluegill') to Frostean bildungsromans ('Bess'), from a southern gothic reminiscent of Flannery O’Connor or Yoknapatawpha County ('El Paso', ‘Country’) to urban noir 
and beat homages ('Gemcrack’ and 'Black Tickets’).

However, whilst gesturing towards the impressive diversity within Phillips' short fiction, it is still worth repeating those core elements that have been traced here. Phillips is interested in clashes: between old and young, black and white, male and female, sick and well, working class and middle class, straight and gay, sane and insane. A phrase appears in 'Gemcrack' that captures the key dimension to these collisions: 'clues to the underside'. Black Tickets and Fast Lanes search for clues to the underside of the body (in sexual drives, disease and waste), clues to the underside of consciousness (in dreams and madness) and clues to the underside of society (in the underclass, oppressed racial groups and the young). Given this predilection for the underside, dirty sub-realism might be more appropriate than dirty surrealism. Whichever label is invoked the adjective is crucial, because Jayne Anne Phillips writes wonderfully dirty books.

\section{Notes}

${ }^{1}$ The term 'dirty realism' was coined by Bill Buford and he also provided the earliest definition of this school in terms on its concentration on the underbelly of contemporary American life. (See Granta 8, 'Dirty Realism: New Writing from America', (Harmondsworth; Penguin, 1983), Bill Buford (ed.), and Granta 19, 'More Dirt', (Harmondsworth; Penguin, 1986), Bill Buford (ed.)). Nick Hornby provides a suitably succinct if somewhat skeptical clarification of the term 'minimalist' in relation to this school, but goes on to classify Phillips as a 'dirty surrealist.' (See Contemporary American Fiction, (London; Vision, 1992)). Joanna Price elucidates the term 'New Realist' writing in her reading of Phillips' Machine Dreams' (see 'Remembering Vietnam: Subjectivity and Mourning in New Realist Writing', Journal Of American Studies, Vol.27, No.2, 1993, pp.173-186) and Linden Peach, as well as exploring most of the alternative definitions, also refers to the concept of 'K-Mart Realism (see 'K Marts and Lost Parents: 'Dirty Realism' in Contemporary American and Irish Fiction', Critical Survey, Vol.9, No.2, 1997, pp.61-79).

${ }^{2}$ Hornby, Nick, Contemporary American Fiction, p.33 and p.93.

${ }^{3}$ Phillips, Jayne Anne, Black Tickets, (Harmondsworth; Penguin, 1981) and Fast Lanes, (London; Faber, 1987). All subsequent references are to these editions.

${ }^{4}$ Kristeva, Julia, Powers of Horror: An Essay on Abjection, (New York: Columbia University Press,1982), p.4.

${ }^{5}$ Sontag, Susan, Illness as Metaphor, (London; Penguin, 1991), p.3.

${ }^{6}$ ibid. p.151

7 In a similar vein, 'El Paso' (in Black Tickets) is organised around a colour symbolism and geography extravagantly lifted from the colonial imagination: Fair Maidens and Dark Ladies, a cold North and a hot, sensual South.

8 This and similarly lush figurative passages throughout her fiction are, I think, good examples of a tendency towards stylistic indulgence that precludes Phillips' work from the 
'new minimalist' label.

9 Kristeva, Julia, 'Stabat Mater', in Furman, N., 'The Politics of Language: Beyond the Gender Principle', in Making a Difference: Feminist Literary Criticism, G. Green and C.Kahn, (eds.), (London: Methuen, 1985), p.48.

10 Kristeva, Julia, 'The Adolescent Novel' in Fletcher, John and Benjamin, Andrew (eds.), Abjection, Melancholia and Love: the work of Julia Kristeva, (London; Routledge, 1990), p.8.

11 ibid. p.9.

12 Price, Joanna, 'Remembering Vietnam: Subjectivity and Mourning in New Realist Writing', p.174.

13 ibid, p.175.

14 ibid. p. 174.

15 ibid. pp.179-180.

${ }_{16}$ Mason, Bobbie Ann, quoted in Hornby, Nick, Contemporary American Fiction, p.86.

17 Price, Joanna, 'Remembering Vietnam: Subjectivity and Mourning in New Realist Writing', p.186.

18 As she goes on to explore in her debut novel, Machine Dreams, Phillips is fascinated by how much of the real is now defined in terms of the media through which it moves. For a full discussion of this aspect of the novel see Brian Jarvis, Postmodern Cartographies: the Geographical Imagination in Contemporary American Culture, (London; Pluto Press, 1997). 
(1) 